\title{
SPECIAL IS AS SPECIAL DOES
}

NOtHING IS VERY SPECIAL in the least about special collections unless they are made meaningful. The meaning derives from the interaction of the artifact and the individual mind and heart; Rachel Howarth, in a companion piece to this one, has provided many examples of such encounters. Quite simply, the manuscripts, books, maps, photographs, and other formats in our charge are significant only to the extent that they serve us and, more important, our patrons. Thus, special is as special does.

In the past fifty years, we have seen special collections evolve radically, from the prewar treasure room to the rare book and manuscripts room, and finally to the modern special collections department. This reflects a trend toward increasing breadth of coverage in collection development and a welcome movement away from elitism in the public services sphere. Despite this welcome shift, however, special collections still have the dubious honor of being the most misunderstood part of the library. In the future, it will not be sufficient for us merely to assert the "specialness" of our special collections. Users, library administrators, and governing boards alike will demand evidence that those collections are accessible, productive, active, and, yes, sometimes even revenue-producing resources.

As a result, special collections are likely to become digital publishers, perhaps forming consortia with commercial publishers. Every large gift will be scrutinized to determine whether the cost of cataloging and 
storing the collection is commensurate with its research value. Education officers to assist in the interpretation of our materials will become fixtures in the larger special collections. Librarians will finally take some heed of William Matheson's and Marcus McCorison's warnings about the mindless duplication of rare book collections. Commercial licensing fees will find general acceptance. Perhaps a few realistic cooperative collection development initiatives will even be spawned. Special collections in the twenty-first century, unlike poems, should not "be" but "mean." 